\title{
Environmental and Personality Influences on Nurse Discipline Public Health Center
}

\author{
Suprapto $^{1}$, Trimaya Cahya Mulat ${ }^{2}$, Nur Syamsi Norma Lalla ${ }^{1}$ \\ ${ }^{1}$ Senior Lecturer, Department of Public Health Sciences, ${ }^{2}$ Senior Lecturer, Department of Nursing Management, \\ Faculty of Nursing, Politeknik Sandi Karsa Makassar 90245 Makassar, South Sulawesi, Indonesia
}

\begin{abstract}
Introduction: Discipline is a benchmark to find out whether the role of a manager or leader as a whole can be implemented well or not.

Method: This research is a quantitative study supported by qualitative data with cross-sectional study design.

Results: The test with the chi-squer test of personality and environmental factors obtained a p-value of 0.827 that $\mathrm{Ha}$ was rejected and $\mathrm{H} 0$ was accepted so that there was no influence between personality and environmental factors on the discipline of nurses in Barombong Public Health Center, Makassar.

Conclusion: There is no influence between personality and environmental factors on the discipline of nurses in the Makassar City Barombong Health Center. This research can be used as a reference material for learning about nurse discipline and is expected for health workers to be used as input for carrying out their duties.
\end{abstract}

Keywords: Discipline, Personality, Environment.

\section{Introduction}

World Health Organization (WHO), that in order to improve the performance of nurses both in the enforcement of discipline of nurses must be able to provide comfort and satisfaction to nurses as an appreciation for the performance they do. Based on medical record data obtained at the Makassar City Barombong Health Center, that the total number of nurses is 124 people $^{(1,2)}$.

\section{Corresponding Author:}

\section{Suprapto}

Senior Lecturer, Department of Public Health Sciences, Faculty of Nursing, Politeknik Sandi Karsa Makassar

90245 Makassar, South Sulawesi, Indonesia

e-mail: atoenurse@gmail.com

Tel: +6281242800025

Fax: +62(0411) 591279
Nurses as one of the important assets in the management of health facilities in hospitals and health centers have a very important role, other than as paramedics to treat patients, because of these very important tasks, nurses should have a high work discipline, for example about work discipline is associated with risks that may occur, for nurses who are not disciplined delays in handling patients (even in seconds) will greatly jeopardize the safety of patients' lives $^{(3)}$.

Discipline is a matter of benchmarks to determine whether the role of a manager or leader as a whole can be implemented properly or not. Nursing is one of the professions in hospitals and dipuskesmas that plays an important role in the implementation of efforts to maintain the quality of health services in health centers and hospitals. Health services at puskesmas are a form of service provided to clients, by a multi-disciplinary team including the nursing team. The nursing team is a member of the health team that faces client health problems for 24 hours continuously ${ }^{(4)}$. 
Public health center has a role in efforts to improve the highest public health. In an effort to achieve the degree of public health, Public health center and hospitals organize affordable and quality health services for the community ${ }^{(5)}$. To improve services, one important factor that must be considered by hospitals and health centers is Human Resources (HR). Explain that the success of an institution is determined by two main factors, namely Human Resources or Labor and supporting infrastructure or work facilities. People who work or become members of an organization called personnel, employees, employees, workers, labor, and others $^{(6,7)}$.

\section{Material and Method}

This study uses quantitative research method supported by qualitative data with a cross sectional or cross sectional research design, where the independent variable (the influencing variable) and the dependent variable (the affected variable) are measured and observed at the same time. The sample in this study amounted to 50 respondents. with cross sectional or cross sectional research design, using non-rundem sampling method with criteria determined by researchers.

\section{Findings:}

Table 1. Personality Factor Analysis of Nurses' discipline at the Makassar City Barombong Health Center

\begin{tabular}{|c|c|c|c|c|}
\hline \multirow{2}{*}{ Personality Factor } & \multicolumn{2}{|c|}{ Discipline } & \multirow{2}{*}{ Total } & \multirow{2}{*}{ Value $p$} \\
\hline & Good & Not Good & & \\
\hline Good & 47 & 0 & 47 & \multirow{3}{*}{0,827} \\
\hline Not Good & 0 & 3 & 3 & \\
\hline Total & 7 & 3 & 50 & \\
\hline
\end{tabular}

Source: Primary data processed, 2019

Table 2. Analysis of Environmental Factors on Nurse Discipline at the Makassar City Barombong Health Center

\begin{tabular}{|l|c|c|c|c|}
\hline \multirow{2}{*}{ Environmental Factor } & \multicolumn{2}{|c|}{ Discipline } & \multirow{2}{*}{ Total } & \multirow{2}{*}{ Value p } \\
\cline { 2 - 4 } & Good & Not Good & 47 & \multirow{2}{*}{0,827} \\
\hline Good & 47 & 0 & 50 & \\
\hline Not Good & 0 & 3 & 50 \\
\hline
\end{tabular}

Source: Primary data processed, 2019

\section{Discussion}

The results of the analysis of personality factors on the discipline of nurses in the Makassar City Barombong Health Center after being given a questionnaire showed a significant value of $0.827>0.05$ which means that Ha was rejected and $\mathrm{H} 0$ was accepted. This shows that personality factors on discipline have no effect. An important factor in a person's personality is the value system adopted, the value system in this case is directly related to discipline. Values that uphold the discipline taught or instilled by parents, teachers, and communities are used as a frame of reference for the application of discipline in the workplace. The value system will be seen from one's attitude and attitude is expected to be reflected in behavior.

Research conducted shows that there is no meaningful relationship between motivation for working conditions and work discipline. That there is no meaningful relationship between work environment conditions and nurse performance. Other research 
that is in line is to conclude that there is no significant relationship between developing opportunities and work discipline. Thus it can be concluded that environmental factors have no influence on the discipline of nurses at the Makassar City Barombong Health Center ${ }^{(8,9)}$.

Efforts to instill discipline are basically instilling values in order to achieve the goals of the Puskesmas from within namely the morale or enthusiasm and awareness of the nurse of the importance of work discipline, discipline because of compliance with existing commitments, and compliance based on identification. The results of the analysis of environmental factors on nurse discipline at the Makassar City Barombong Health Center after being given a questionnaire showed a significant value of $0.827>0.05$ which means that Ha was rejected and $\mathrm{H} 0$ was accepted. This shows that environmental factors on discipline had no effect.

This study is in line with research that analyzes the effect of work environment and work stress on employee performance with the conclusion that the positive influence of work environment with performance is rejected because a significant value of 0.102 is obtained. Results of analysis using chi-square obtained $\mathrm{p}$ value $=0.332$ or $\mathrm{p}$ value $>0.05$. Thus, $\mathrm{H} 0$ is accepted and $\mathrm{Ha}$ is rejected, so it can be concluded that there is no meaningful relationship between work environment and the performance of inpatients at Tugurejo Hospital Semarang ${ }^{(10)}$.

This study is in line with the results that there is no relationship between education, work environment conditions and the quality of nursing services in the Emergency Room Installation of the Salewangan Maros Regional Hospital with $p>0.05$, and there is a relationship between workload and the quality of nursing services in the Room of the Nursing Installation. Emergency Regional Hospital of Salewangan Maros with $p=0.003$. There is a relationship between factors interpersonal relationships with the quality of nursing services in the Emergency Room Installation of the Salewangan Maros Regional Hospital with $p=0.004$. Based on the results of this study it was concluded that the factors of work stress nurses with the quality of nursing services in the Emergency Room Installation of the Salewangan Maros Regional Hospital were workload factors and interpersonal relationships ${ }^{(11)}$.

Contrary to the results of the study that the work environment has a positive but not significant effect on organizational commitment. Work discipline and work stress have a positive and significant effect on organizational commitment the work environment has a positive and significant effect directly on nurse performance without having to go through organizational commitment. Work discipline directly influences but not significantly to nurse performance, but indirectly work discipline has a positive and significant effect on nurse performance through organizational commitment. Thus it can be concluded that personality and environmental factors have no influence on the discipline of nurses in the Makassar City Barombong Health Center ${ }^{(12)}$.

\section{Conclusions}

Based on research that has been done, it can be concluded that; there is no influence between personality and environmental factors on the discipline of nurses in the Makassar City Barombong Health Center. The results of this study can be used as a reference material for learning about the discipline of nurses for health workers so that this research input material to carry out their duties properly.

Conflict of Interest: There are no conflicts of interest between the authors.

\section{Source of Funding: Self}

Ethical Considerations: The investigator obtained clearance from the Institutional ethics committee before collecting data and has taken informed written consent from each participant. Participant information sheet was also shared which assured privacy and confidentiality of data.

\section{References}

1. Rekammedik. Rekam Medik Public health center Barombong Kota Makassar. Makassar: Public health center Barombong; 2019.

2. Baynham M, Lea M, Stierer B. Academic writing in new and emergent discipline areas. Supporting Lifelong Learning: Perspectives on learning. 2002;1:188.

3. Yatnikasari A. The Relationship Between Retention Program and Organizational Nurse Organizational Commitments at Harapan Kita Hospital Jakarta. Tesis; 2010.

4. Yulian R, Yeni Y. Optimization of Puskesmas Services in Improving the Quality of Community Health Services in Kubu Raya Regency, West 
Kalimantan Province. Journal of Motivation Management. 2017;13(2):850-67.

5. Rifai M, Madjid U, Ismunarta I. Policy Implementation of Minimum Service Standards in the Health Sector at Garawangi Health Center, Kuningan Regency, West Java Province. Journal of Government Politics. 2016;9(1):25-43.

6. Dessler A. Introduction to modern climate change. Cambridge University Press; 2015.

7. Nawawi. Strategic Management: Non-Profit Organizations in Government. Yogyakarta: UGM; 2005.

8. Meidian FA. Analysis of the Relationship between Work Motivation Factors and Non-Medical Staff Work Discipline in Administration Building $\mathrm{X}$ Hospital. Thesis, Faculty of Public Health, University of Indonesia Thing. 2012;1-21.
9. Prasojo S. Relationship between characteristics and motivation with the work discipline of implementing nurses in inpatients at RSUD Batang. 27182; 2005.

10. Dwi Septianto DS, Lataruva E. The influence of work environment and work stress on the performance of study employees at PT Pataya Raya Semarang. Universitas Diponegoro; 2011.

11. Suprapto S. Nursing Work Stress Factors That Are Related to the Quality of Nursing Services in the Emergency Care Installation of the Salewangan Area, Maros Regency. Journal Health Scientific Sandi Husada. 2016;4(1):1-10.

12. Rumoning MH. Effect of Work Environment, Work Discipline and Job Stress on Organizational Commitment in Improving Nurses' Performance in Asmat District Hospital. EMBA Journal: Journal of Economic Research, Management, Business and Accounting. 2018;6(2). 